\title{
就怕心不專
}

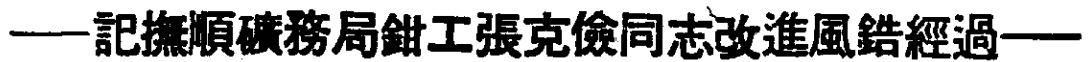

\section{一 譏诚化}

去年紅五月。邢時候正閙材料困難。棚棚 子用的釘子眼看着供不上了, 井下工龙整天

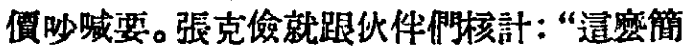
單的東西咱們自己不能做?"偏巧有浇個工友

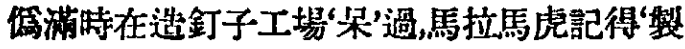
釘機' 的樣子。於是大家你想一默, 我想一點 的奏對一起, 張克俭就捉摸着畫圖。把“梨釘 機・算造㑁來了，一試䮑踓然不太好使，但釘 子是有辦法了。

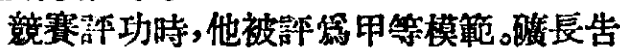
柧他:“你們把風鋯研究研究吧! 沒俑風鋯,并 下就機械化'不起來!”當時是:井下差不多都 是用手鋯刨・有幾台日本娍鋯也都鹤的鹤壤 的壇了，而且還不大好使。他答應下来了： “行! 試試看!”因俘他知道:“只有大笔率心努 力, 還有作不到的事?” 行政上給他們組織侽 “研究小組”。開始'研究, 起來了。矌長的話老在 他們胘子襄轉图:“浔有風鋯不能“機械化’!”

\section{二 失攻了}

汥有圖樣，他們就把日本人扔下的各式

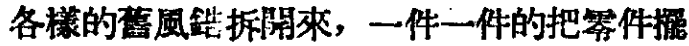

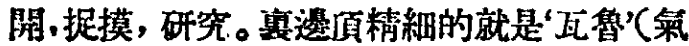
閂)，三倜圆鐝板，一個比一個厚，一個板上就 有十多個風眼。做的特别精納, 車完還得上平

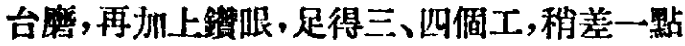

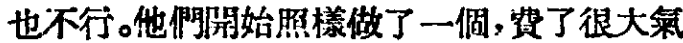
力, 做的又大又沉，二十四厅。拿井下去一“比 畫',打'是“打了了,力量也行, 就是愛出毛病,

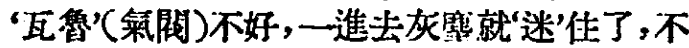
能再勤, 而且“攻門”不好使,還漏策。接着又照 溙改了點作一個小的,還是不行: ‘篓門”好些 了, 但 “正鲁” (氣閜)還是老仙毛病,有點灰進

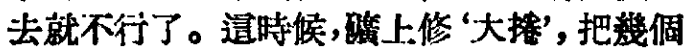
工发調去了。風鍇的研究就故下了。

\section{三范了迷}

張克儉腦子赛到老沼蜼開“風錯”。新紀錄

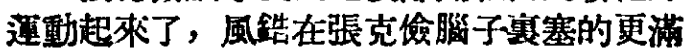
了。那时候,他總是想:怎础能把“瓦魯'(氣閂) 缩好呢?

十月,蕉聯工程師來了, 在老虎台醉視自

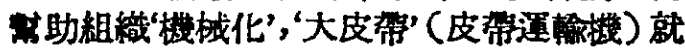

要用上了。绿聯工程師講過的: “蝶聯探煤已 經完全用機器了。”立刻在工友們中間像 “神 話”般的流傅起來。這百叫张克儉着急了。他 忽然想起酹上新來的蘇聯風鋯來了, 下玨後 他把蘇聯風鈚拆來看; 但蘇泑的風鋯比日本 的更精細, “氣閵”是帶流珠工的。不用說别的, 就是滚珠也難找到呵。但足他外菂了：“道束 西是可以變㧼的,不一定荘日本那老㧼了!!

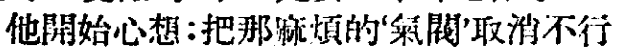
麼? 能不能再简單啙, 㕷們自己能做呢?

天天在班上想，回家也想，吃饭想，唩學

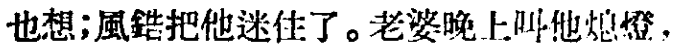
跟他吵架, 他不学她。恣渚他有蛅文化, 就硬 找日本書看:晚上睡不等, 拿根鍇篗老比星符

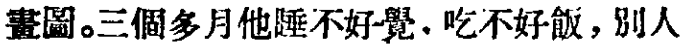
說他溲了。到底他找着了, 日本書上有那個沼 有“風閵”的風鋯, 說古侍過。他高興的叫起 來:“找着了!取消它!”

\section{四 取消它}

第二天旦晨.找行政和賞其工會腅:黨政 工支持他：“大䏵試一下看!”他自己捉摸一张 圖, 用三倜工試驗着作了一僻小的把“采蔺”取

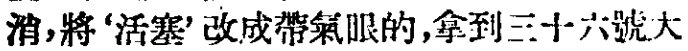
掌去一試䐘,行是行, 力量太小了。他自己又 浔有多大信心了! 力量小怎能付呢?局設到科 昔工師找他去.肯定了他的信心:“行。這樣的

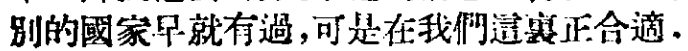

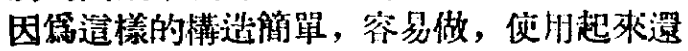

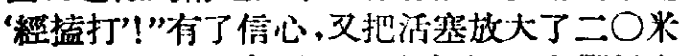
厘.做了個大的拿到非下試駿洔,工龙們很高 興: “這小傢伙及輕俏又有勁, 就是“把”不結 䔡?”

\section{五 就怕心不專}

五月十六號，局兖的工程所和酷長、科 長和張克俭，到井下去作試驗。除了侍些小正

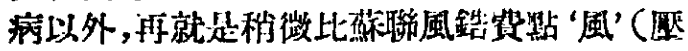
縮空氣)以外，是成功了。顶可贵的是:這個風 鵨我們自己可以做。

局長獎謜了張克俭同志，並且把遭個風 鋯交給工程師帮助研究把那些小毛病克服。 張克偷對同伴們馀:“解放了。能啥就幹啥，還 有㕷們工人作不到的事! 就怕不專心!”

(方碑) 